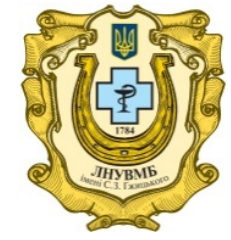

Ukrainian Journal of

Veterinary and Agricultural Sciences

http://ujvas.com.ua

Stepan Gzhytskyi National University of Veterinary Medicine and Biotechnologies Lviv

original article | UDC 636.598:636.082 | doi: 10.32718/ujvas1-2.02

Volume 1

Number 2

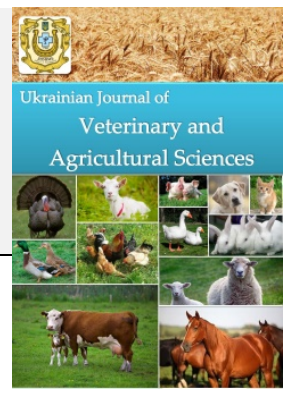

\title{
Meat quality of obroshyno grey geese while their cultivation
}

\author{
M.D. Petriv ${ }^{1}$, L.Ia. Sloboda ${ }^{1}$, O.M. Sloboda ${ }^{2}$ \\ ${ }^{1}$ Institute of Agriculture of Carpathian region of Ukraine NAAS, Grushevskogo Str., 5, Obroshino, 81115, Ukraine \\ ${ }^{2}$ Stepan Gzhytskyi National University of Veterinary Medicine and Biotechnologies Lviv, Pekarska Str., 50, Lviv, 79010, Ukraine
}

\section{Article info \\ Received 05.09.2018 \\ Received in revised form 10.10.2018 \\ Accepted 11.10.2018 \\ Correspondence author \\ Oleh Sloboda \\ Tel.: +38-067-261-66-87 \\ E-mail: oleh.sloboda@gmail.com \\ (C) 2018 Petriv M.D. et al. This is an open-access article distributed under the terms of the Creative Commons Attribution License, which permits unrestricted use, distribution, and reproduction in any medium, provided the original author and source are credited.}

\section{(cc) $\mathrm{BY}$}

Contents

1. Introduction

2. Materials and methods .......

3. Results and discussion ....... 8

4. Conclusions ................ 10

References ...................... 10

\begin{abstract}
The process of cultivating obroshyno gray geese improved their meat qualities. In particular, we determined by our researches that, based on the indicators of live weight, the males of the II group (4726 g) prevailed geese of the I and II groups $(1.02 \%)$, while females of the II group $(4153 \mathrm{~g})$ prevailed all groups by $4.19 \%$. The weight of noneviscerated males of the II group was $4116 \mathrm{~g}$, which is $3.78 \%$ higher than that of males of the group I, while females of the group II ( $3461 \mathrm{~g}$ ) surpassed other geese by this indicator by $5.10 \%$. The weight of eviscerated of carcasses of males of the II group was $3211 \mathrm{~g}$, which is $3.5 \%$ higher than that of males of group I, while females of the second group (2738 g) surpassed others by $6.6 \%$. The outcome of edible parts in the young geese of experimental groups was quite high, but the highest was the young in the second group. In males of the second group, this inicator was $61.5 \%$, and females $-58.9 \%$. The weight of the chilled carcasses of males of the II group was $3120 \mathrm{~g}$, which was $3.93 \%$ higher than that of the males of the group I, while the females of the second group $(2691 \mathrm{~g})$ surpassed others by $7.04 \%$. The weight of the skin with subcutaneous fat in males of the second group was $706 \mathrm{~g}$, which is $3.67 \%$ higher than that of male of the group I $(681 \mathrm{~g})$, while females of group II $(632 \mathrm{~g})$ surpassed others by $4.64 \%$. The mass of internal fat in males of the II group was $111 \mathrm{~g}$, which is $15.62 \%$ higher than that of male of the I group $(95 \mathrm{~g})$, while females of II group ( $72 \mathrm{~g}$ ) exceeded others by $12.5 \%$. The weight of the muscles in the males of the second group was $1695 \mathrm{~g}$, which is $8.58 \%$ higher than that of the male of the group I $(1561 \mathrm{~g})$, and the females of the second group $(1399 \mathrm{~g})$ surpassed others by this indicator - by $7.6 \%$. The obtained data indicate that the most intense accumulation of dry matter in the chest muscles up to 9 weeks of age occurs in geese of the II group. A similar situation is observed in the femoral muscles. At 9 weeks of age, the males of the second group had $29.74 \%$ of the dry matter in the breast muscle of the crude mass, females $-27.35 \%$ of the crude mass, and in males of the I group $-27.74 \%$, of females $-27.30 \%$. The same regularity in the content of dry matter is noted in the femoral muscle. The accumulation of protein in the studied muscles of geese, as the main indicator of meat quality, was in accordance with the general laws. The highest rate was in the thoracic and femoral muscles of males and females of the II group. The highest level of total nitrogen content in the muscles was found in males of the second group. In experimental geese, the accumulation of protein nitrogen in the chest muscle is higher than in the muscles of the legs. This indicator is higher in males than females. According to the content of albuminous nitrogen in the chest muscle, the highest rate was observed in males II group (3425 mg\%). Non-protein nitrogen in the chest muscles and leg muscles increased to 9 weeks of age.
\end{abstract}

Key words: geese, growth rate, meat and slaughter quality, morphological and chemical composition of carcasses, nitrogen exchange.

\section{Citation:}

Petriv, M.D., Sloboda, L.Ia., \& Sloboda, O.M. (2018). Meat quality of Obroshyno grey geese while their cultivation. Ukrainian Journal of Veterinary and Agricultural Sciences, 1(2), 7-10.

\section{Introduction}

The production of goose on an industrial basis - requires the introduction of a scientifically based system of breeding, keeping, feeding farm birds, which includes a complex of zootechnical, veterinary and organizational measures that ensure uninterrupted production of eggs, meat, poultry feathers at the lowest cost of manual labor and feed The geese have a high growth rate (Aghdam Shahryar and Lotfi, 2015; Zaplatynsky, 2017; Orishchuk et al., 2017). The live weight of one goose from the one day age to 56-60-day-old age increases by $40-45$ times and reaches an average of $4 \mathrm{~kg}$ at a cost of $1 \mathrm{~kg}$ of weight gain of no more than $3 \mathrm{~kg}$ of feed. The greatest intensity of growth at the lowest cost of feed in geese is observed in the first three weeks of life (Solé et al., 2016). Our research on the breeding of young geese of grey obroshyno breed has already been highlighted by us in the publications (Petriv et al., 2017; Sloboda and Sloboda, 2018). The purpose of this development is to preserve the obroshyno breed group of geese with improved productive qualities. In 2017, the task was to improve the productive qualities of the obroshyno gray geese and expand the population when they were cultivated among themselves. The research work is aimed at preserving, improving and expanding the population of obroshyno gray geese. 


\section{Materials and methods}

The researches were carried out by us in the laboratory of small livestock breeding IGGKR NAAS and SE "Hrusiatychi" according to generally accepted methods in poultry farming.

According to external features, selection of geese with well-developed meat forms was carried out in the absence of defects in the exterior, and the measurements of body sections were associated with meat forms. In the process of cultivation, the conservation of young animals up to 9 weeks of age is taken into account.

It was used only the gray bird of the obroshyno breed group in the experiments.

The young, from one day of age, have been signed and put up for cultivation. They were fed to a 3-week-old age with specially developed mixed fodder taking into account all the indicators of normalized feeding. By the 21-week-old age, control was carried out for the growth and development of the geese (weighing for ten days and taking the main measurements of body items).

In 2017, the breeding work was carried out with the use of intrabred breedingof obroshyno gray geese (Table 1).

Table 1

Scheme of the research, $(n=50)$

\begin{tabular}{lcc}
\hline+ & \multicolumn{2}{c}{ Breeds and breed groups } \\
\cline { 2 - 2 }$-3 \phi$ & $\mathrm{OC}-3 \hat{\delta}$ & $\mathrm{OC}-5 \hat{\jmath}$ \\
$\mathrm{OC}-5+$ & $\mathrm{X}$ & $\mathrm{X}$ \\
\hline
\end{tabular}

Note: OC - Obroshyno grey

Table 2

Dynamics of the living mass of geese, $\mathrm{kg}(\mathrm{M} \pm \mathrm{m})$
The number of geese not involved in the research in 2017 was kept separate and received from them young animals were implemented by farms and population.

For a more complete description of the processes of growth and development of geese in different ages, measurements of the items of their bodies were carried out. In our work, we used the following basic measurements of the body's items: breast chest, body length, stag and plexus. In all ages, geese of the second group prevailed their peers according to these indicators. The scheme and conditions of the research, their methods and some of the results obtained, in particular the data of measurements of the body of the subject geese, are given by us in (Sloboda and Sloboda, 2018).

\section{Results and discussion}

It is known that the important feature of the young is the different growth rate in different periods of development. The most intensive relative increase in live weight was noted in the first month of life of young, so the increase in the 1 st group was males $-175.7 \%$ and in the II $-176.0 \%$, and in females, respectively, $158.2 \%$ and $165.6 \%$.

The study of meat qualities is important for the characterization of the productivity of geese. To study the meat qualities we carried a slaughter of birds at 9 weeks of age and identified the morphological composition of the carcass, which is important in the study of the interior and meat characteristics of geese (Table 3 ).

\begin{tabular}{cccccc}
\hline \multirow{2}{*}{ group } & \multicolumn{5}{c}{ Geese age } \\
\cline { 2 - 6 } & 1 day & 4 weeks & 9 weeks & 12 weeks & 21 weeks \\
\cline { 2 - 6 } & $0.103 \pm 0.09$ & $1.81 \pm 0.29$ & $4.52 \pm 0.40$ & $5.30 \pm 0.15$ & $5.67 \pm 0.25$ \\
I & $0.104 \pm 0.04$ & $1.82 \pm 0.35$ & $4.61 \pm 0.53$ & $5.37 \pm 0.21$ & $5.81 \pm 0.35$ \\
\hline II & $0.98 \pm 0.30$ & $1.55 \pm 0.15$ & Female & $4.83 \pm 0.12$ & $5.28 \pm 0.23$ \\
\hline I & $0.99 \pm 0.08$ & $1.64 \pm 0.17$ & $3.86 \pm 0.19$ & $4.88 \pm 0.16$ & $5.46 \pm 0.30$ \\
\hline II & & & & &
\end{tabular}

Table 3

The results of the slaughter of geese in experimental groups at 9 weeks of age, $(M \pm m) n=3$

\begin{tabular}{|c|c|c|c|c|c|c|}
\hline \multirow{3}{*}{ Group } & \multirow{3}{*}{ Age } & \multirow{3}{*}{$\begin{array}{c}\text { Pre slaughtered live mass, gr. } \\
\qquad \mathrm{M} \pm \mathrm{m}\end{array}$} & \multicolumn{4}{|c|}{ Carcass mass, gr } \\
\hline & & & \multicolumn{2}{|c|}{ Non processed } & \multicolumn{2}{|c|}{ processed } \\
\hline & & & $\mathrm{M} \pm \mathrm{m}$ & $\%$ & $\mathrm{M} \pm \mathrm{m}$ & $\%$ \\
\hline \multirow{2}{*}{ I } & male & $4591 \pm 33$ & $3966 \pm 52$ & 86.4 & $3101 \pm 40$ & 67.5 \\
\hline & female & $3986 \pm 49$ & $3293 \pm 45$ & 82.6 & $2567 \pm 45$ & 64.4 \\
\hline \multirow{2}{*}{ II } & male & $4726 \pm 25$ & $4116 \pm 59$ & 87.1 & $3211 \pm 39$ & 67.9 \\
\hline & female & $4153 \pm 40$ & $3461 \pm 19$ & 83.3 & $2738 \pm 39$ & 65.9 \\
\hline
\end{tabular}

According to the indicators of carcass pre slaughtered live weight, the males of II group (4726 g) prevailed for the same age groups of the I group by $1.02 \%$, while the females of II group (4153 g) surpassed their age by $4.19 \%$. The weight of non-processed carcasses of males of the II group was $4116 \mathrm{~g}$, which is $3.78 \%$ higher than that of males of group I, while females of group II (3461 g) surpassed their peers by this indicator by $5.10 \%$. The weight of processed carcasses of males of the II group was $3211 \mathrm{~g}$, which is
$3.5 \%$ higher than that of males of group I, while females of the second group $(2738 \mathrm{~g})$ surpassed their age by $6.6 \%$.

The outcome of edible parts (Table 4) in the young of experimental groups was quite high, but the highest was the young in the second group. In males of the second group, this indicator was $61.5 \%$, and females $-58.9 \%$.

Morphological analysis, as a method, is important in the study of interior and meat characteristics of geese. 
While analyzing the data in Table 4 , it should be noted that the supposedly higher mass of cooled carcass of skin with subcutaneous fat, internal fat and muscle of males of the second group. The weight of the chilled carcasses of males of the II group was $3120 \mathrm{~g}$, which was $3.93 \%$ higher than that of the males of group I, while the females of the second group (2691 g) surpassed their peers by $7.04 \%$.

The weight of the skin with subcutaneous fat in males of the II group was $706 \mathrm{~g}$, which is $3.67 \%$ higher than that of the male group I $(681 \mathrm{~g})$, while females of the second group $(632 \mathrm{~g})$ surpassed the geese of the same age by $4.64 \%$

\section{Table 4}

Morphological content of geese carcasses of the researched groups, gr. and $\%$ to the mass of the carcass $(M \pm m) n=3$

\begin{tabular}{|c|c|c|c|c|c|c|c|c|c|c|c|c|c|}
\hline \multirow[t]{2}{*}{ Group } & \multirow[t]{2}{*}{ Gender } & \multirow{2}{*}{$\begin{array}{c}\text { Pre slaughter } \\
\text { live mass }\end{array}$} & \multirow{2}{*}{$\begin{array}{c}\begin{array}{c}\text { Mass of the } \\
\text { chilled } \\
\text { carcass }\end{array} \\
\mathrm{M} \pm \mathrm{m}\end{array}$} & \multicolumn{2}{|c|}{$\begin{array}{l}\text { Skin with the sub } \\
\text { skin fat }\end{array}$} & \multicolumn{2}{|c|}{ Internal fat } & \multicolumn{2}{|c|}{ Muscles } & \multicolumn{2}{|c|}{ Bones } & \multicolumn{2}{|c|}{$\begin{array}{l}\text { Outcome of edible } \\
\text { part of body }\end{array}$} \\
\hline & & & & $\mathrm{M} \pm \mathrm{m}$ & $\%$ & $\mathrm{M} \pm \mathrm{m}$ & $\%$ & $\mathrm{M} \pm \mathrm{m}$ & $\%$ & $\mathrm{M} \pm \mathrm{m}$ & $\%$ & $\mathrm{M} \pm \mathrm{m}$ & $\%$ \\
\hline \multirow{2}{*}{ I } & & $4591 \pm 33$ & $3002 \pm 50$ & $681 \pm 31$ & 14.8 & $96 \pm 5$ & 2.1 & $1561 \pm 36$ & 34.1 & $667 \pm 29$ & 14.5 & 2728 & 59.4 \\
\hline & female & $3986 \pm 48$ & $2513 \pm 29$ & $604 \pm 31$ & 15.2 & $64 \pm 8$ & 1.6 & $1300 \pm 29$ & 32.6 & $548 \pm 19$ & 13.7 & $2392 \pm 19$ & 60.0 \\
\hline \multirow{2}{*}{ II } & male & $4726 \pm 25$ & $3121 \pm 43$ & $706 \pm 29$ & 14.9 & $111 \pm 4$ & 2.3 & $1695 \pm 29$ & 35.9 & $642 \pm 21$ & 13.6 & $2909 \pm 34$ & 61.5 \\
\hline & female & $4153 \pm 25$ & $2691 \pm 30$ & $632 \pm 11$ & 15.2 & $72 \pm 5$ & 1.7 & $1399 \pm 20$ & 33.7 & $589 \pm 10$ & 14.2 & $2449 \pm 30$ & 58.9 \\
\hline
\end{tabular}

Note: edible parts of the carcass are given in relation to pre slaughter live weight

The mass of internal fat in males of the II group was $111 \mathrm{~g}$, which is $15.62 \%$ higher than that of male I group $(95 \mathrm{~g})$, while females of II group $(72 \mathrm{~g})$ exceeded their peers by $12.5 \%$.

The weight of the muscles in the males of the second group was $1695 \mathrm{~g}$, which is $8.58 \%$ higher than that of the male group I (1561 g), and the females of the second group $(1399 \mathrm{~g})$ surpassed their peers by this indicator - by $7.6 \%$.

Thus, on the basis of the above data it is possible to note the best meat productivity of geese II group.

For a more complete description of the meat qualities of the poultry, we carried out a chemical analysis of meat at 9 weeks of age (Table 6).

\section{Table 5}

Development of thoracic and femoral muscles in geese with periods of development, gr.

\begin{tabular}{|c|c|c|c|c|}
\hline \multirow{2}{*}{ Group } & \multirow{2}{*}{ Gender } & \multicolumn{3}{|c|}{ Age periods, days } \\
\hline & & 4 weeks & 9 weeks & 21 weeks \\
\hline \multicolumn{5}{|c|}{ thoracic muscles } \\
\hline \multirow{2}{*}{ I } & males & $33.9 \pm 1.9$ & $450 \pm 3.2$ & $564 \pm 3.4$ \\
\hline & females & $23.4 \pm 4.2$ & $425 \pm 8.0$ & $521 \pm 5.4$ \\
\hline \multirow{2}{*}{ II } & males & $34.4 \pm 2.3$ & $479 \pm 4.0$ & $581 \pm 3.1$ \\
\hline & females & $23.8 \pm 1.9$ & $420 \pm 4.0$ & $515 \pm 3.9$ \\
\hline \multicolumn{5}{|c|}{ femoral muscles } \\
\hline \multirow{2}{*}{ I } & males & $138.3 \pm 3.1$ & $458 \pm 3.1$ & $521 \pm 4.2$ \\
\hline & females & $110.4 \pm 4.0$ & $401 \pm 9.0$ & $463 \pm 4.3$ \\
\hline \multirow{2}{*}{ II } & males & $143.1 \pm 3.1$ & $473 \pm 4.2$ & $541 \pm 6.3$ \\
\hline & females & $119.4 \pm 1.8$ & $417 \pm 5.0$ & $470 \pm 4.6$ \\
\hline
\end{tabular}

Table 6

Chemical composition of the thoracic and femoral muscles of geese at 9 weeks of age, $\%$ of crude mass

\begin{tabular}{|c|c|c|c|c|c|c|}
\hline \multirow{2}{*}{ Group } & \multirow{2}{*}{ Gender } & \multicolumn{5}{|c|}{ Indicators } \\
\hline & & Water & Dry matter & Protein & Fat & Ash \\
\hline \multicolumn{7}{|c|}{ thoracic muscles } \\
\hline \multirow{2}{*}{ I } & males & 72.26 & 27.74 & 20.01 & 6.35 & 1.38 \\
\hline & females & 72.70 & 27.30 & 19.71 & 5.40 & 1.19 \\
\hline \multirow{2}{*}{ II } & males & 70.26 & 29.74 & 21.73 & 6.95 & 1.06 \\
\hline & females & 72.80 & 27.35 & 19.81 & 6.15 & 2.24 \\
\hline \multicolumn{7}{|c|}{ femoral muscles } \\
\hline \multirow{2}{*}{ I } & males & 71.70 & 28.30 & 19.16 & 7.76 & 1.38 \\
\hline & females & 71.24 & 28.76 & 21.08 & 6.60 & 1.24 \\
\hline \multirow{2}{*}{ II } & males & 70.27 & 29.73 & 19.44 & 8.99 & 1.30 \\
\hline & females & 71.08 & 28.92 & 20.78 & 6.75 & 1.23 \\
\hline
\end{tabular}

The obtained data indicate that the most intense accumulation of dry matter in the chest muscles up to 9 weeks of age occurs in geese of the II group. A similar pattern is observed in the femoral muscles. At the 9 weeks of age, the males of the second group had $29.74 \%$ of the dry matter in the breast muscle of the crude mass, females $-27.35 \%$ of the crude mass, and in males of the I group $-27.74 \%$, of females $-27.30 \%$. The same regularity in the content of dry matter is noted in the femoral muscle. The accumulation of protein in the studied muscles of geese, as the main indicator of meat quality, was in accordance with the general laws. 
The highest rate was in the thoracic and femoral muscles of males and females of the II group.

There was no significant difference in the content of fat and ash in the carcasses of experimental groups of geese.
Detection of the features and patterns of metabolism in the body of birds, in particular, the patterns of nitrogen exchange, helps to keep them properly, to select groups when mating in order to increase productivity (Table 7).

Table 7

Content of total, protein and non-protein nitrogen in the femoral and thoracic muscles of geese at 9 weeks of age, mg \% $(\mathrm{M} \pm \mathrm{m}) \mathrm{n}=3$

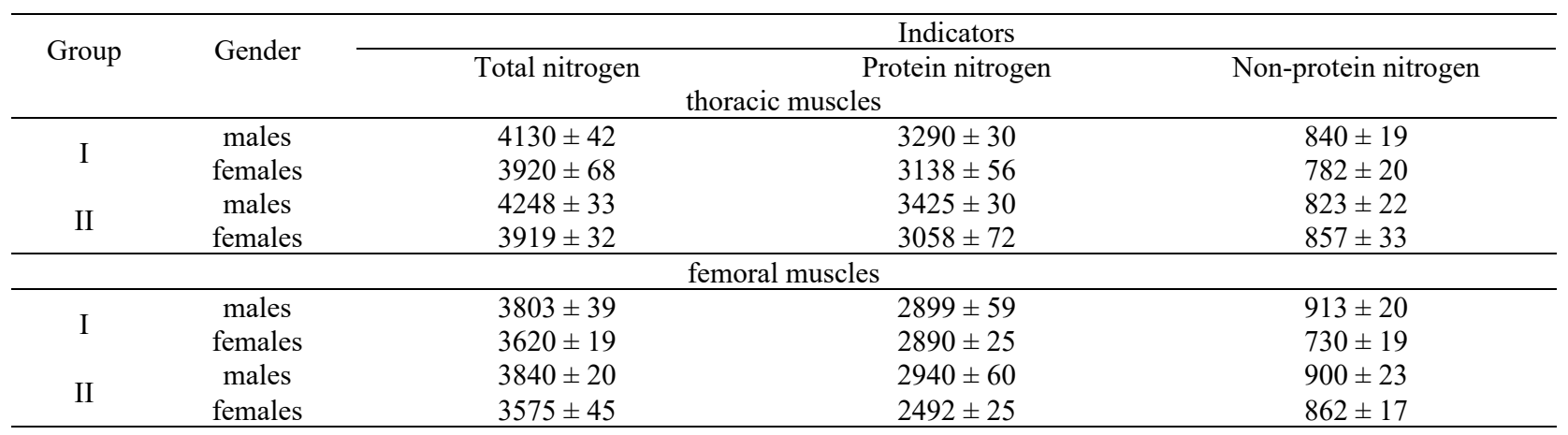

The highest level of total nitrogen content in the muscles was found in males of the second group. In experimental geese, the accumulation of protein nitrogen in the chest muscle is higher than in the muscles of the legs. This indicator is higher in males than females. According to the content of albuminous nitrogen in the chest muscle, the highest rate was observed in males II group (3425 mg\%). Non-protein nitrogen in the chest muscles and leg muscles increased to 9 weeks of age. The highest this figure was in the chest muscles of females of the II group.

\section{Conclusions}

The research work was aimed at preserving, improving and expanding the population of obroshyno gray geese. In the western region, the gray geese of the obroshyno breed are well adapted to local conditions of feeding and keeping. On the basis of the conducted researches the following conclusions are made:

1. Geese of the II group slightly exceeded the peers of the group I for meat qualities (the weight of non processed and processed carcasses and the output of edible parts).

2. When studying the relationship between slaughter quality and weight of muscles, fat and bones in geese carcasses, it is established that the muscle content in poultry carcasses is to the greatest extent correlated with the mass of carcasses, chest muscles, sternum and chest girth.

3. The content of the bones in the boiler depends on the weight of the goose, the length of the shoulder, the forearm and the shin. The main growth of the muscles in the geese ends at 8-9 weeks of age. After reaching this age in the poultry carcasses there is an accumulation of fat and an increase in skin with subcutaneous fat.

Prospects for further research. In the future, we will continue our research to improve the desirable signs of productivity, economic benefits of obroshyno gray geese and increase their number in farms of all forms of ownership in the western region.

\section{References}

Aghdam Shahryar, H., \& Lotfi, A. (2015). The effect of peripheral administration of ghrelin on the performance of growing geese. Archives Animal Breeding, 58(1), 211-216. doi: 10.5194/aab58-211-2015.

Orishchuk, O.S., Ruban, N.A., Tsap, S.V., Mykytiuk, V.V., \& Darmohray, L.M. (2017). Productivity and slaughter index of young gees feeding of soybean lecithin and sunflower. Scientific Messenger LNUVMBT named after S.Z. Gzhytskyj, 19(74), 38-43. doi: 10.15421/nvlvet7409.

Petriv, M., Sloboda, L., \& Slobod, O. (2017). Intensity of growth and development of the young of obroshyno gray geese generation crossed with big gray breed geese, $f$ ii generation, crossed with geese big seed of breed. Scientific Messenger LNUVMBT named after S.Z. Gzhytskyj, 19(74), 219-223. https://nvlvet.com.ua/index.php/journal/article/view/1136.

Sloboda, L., \& Sloboda, O. (2018). Reproductive qualities, exterior features and the quality of the pery of obroshinsky gray geese at their dissolution "inside". Scientific Messenger of Lviv National University of Veterinary Medicine and Biotechnologies, 20(84), 137-142. doi: 10.15421/nvlvet8425.

Solé, M., Negro, S., Membrillo, A., Peña, F., Domenech, V., Verona, J. C., Rubí, M., Valera, M., \& Molina, A. (2016). Association analysis of $\mathrm{g} .68 \mathrm{G} \rightarrow \mathrm{A}$ SNP in CAPN1 gene with carcass and meat quality traits in goose raised in organic dehesa, Arch. Anim. Breed., 59, 423-428, doi: 10.5194/aab-59-423-2016.

Zaplatynsky, V.S. (2017). The correlation between dimensional characteristics, live weight and fluff and feather level of obroshynska gray and obroshynska white natural groups geese. Scientific Messenger LNUVMBT named after S.Z. Gzhytskyj, 19(74), 156-160. doi: 10.15421/nvlvet7435. 